\title{
Shibley Righton
}

Barristers \& Solicitors

COUNSEL

RICHARD E. SHIBLEY, Q.C. BARRY D. LIPSON, Q.C.

BOX 32 - 401 BAY STREET SUITE 1900, THE SIMPSON TOWER TORONTO, ONTARIO, CANADA M5H 221

FAX (416) 2145438

TELEPHONE (416) 363-9381

HAROLD H. ELUOTT, Q.C. JOHN P. BELL

PETER G. NEILSON

WILLLM L. NORTHCOTE

CHARLES M. GASTLE

SANDRA E. DAWE

THOMAS MCRAE

BYRDENA MACNEIL
LESUE S. MASON MICHAEL FTTZPATRICK, Q.C. JONATHAN H. FLANDERS HEIDER M. TRAVASSOS J. PAUL R. HOWARD JANIS E. INGRAM SNEH AURORA JOEL WATSON
BARRY S. WORTZMAN, Q.C. PETER C. WILHAMS

CHARLES SIMCO PETER V. RAYTEK LEONARD D. RODNESS CHRISTINE M. SILVERSIDES HELEN SZYMANSKI

\section{Tory Tory DesLauriers \& Binnington}

Barristers \& Solicitors

For information on our student program, contact:

Dan Donnelly, Student Program Co-ordinator

(416) $865-8163$

ddonnell@torytory.ca

or one of our 1996 - 97 Western articling students:

\author{
Adam Armstrong \\ Geoffrey Gilbert
}

Suite 3000, Aetna Tower, Toronto-Dominion Centre, P.O. Box 270, Toronto M5K 1 N2 


\section{Discover the Value of Electronic Legal Research}

For Your Free CD-ROM Info Kit Call: 1-800-363-3783

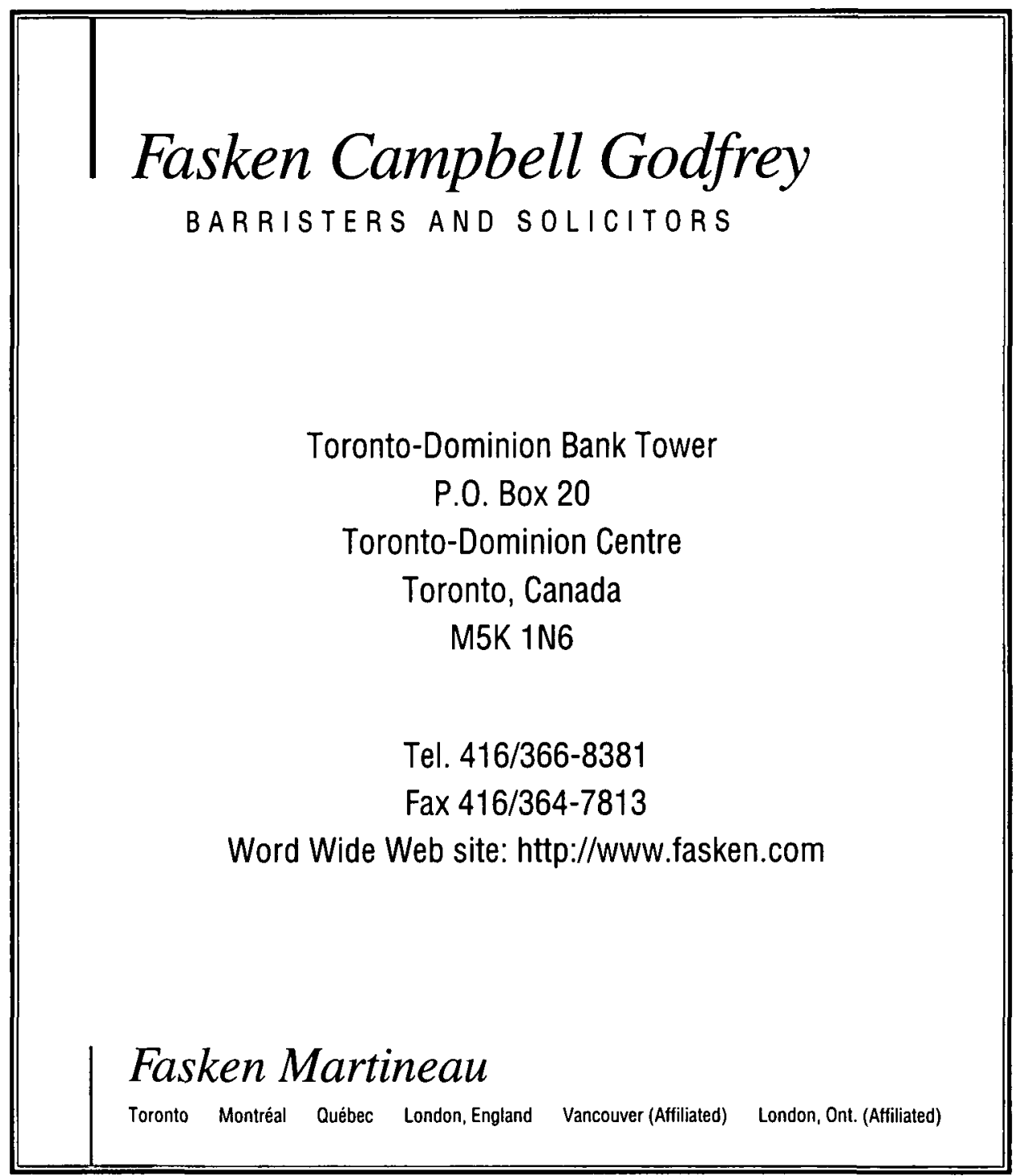




\section{FILION, WAKELY \& THORUP \\ Barristers and Solicitors \\ Practice restricted to Labour and Employment Law on behalf of Management}

150 King Street West,

Suite 2601, Box 32 ,

One London Place

TORONTO, Ontario. M5H 4B6

Telephone: (416) 4083221

Facsinile: (416) 4084814

E-Mail: toronto@filion.on.ca

Web Site: http://www.filion.on.ca

\section{Lang Michener}

BARRISTERS \& SOLICITORS - PATENT \& TRADE MARK AGENTS

Toronto Office

BCE Place

P.O. Box 747

Suite 2500

181 Bay Street

Toronto, Ontario

M5] $2 T 7$

Tel: (416) 360-8600

Fax: (416) 365-1719
We offer a challenging and exciting opportunity to learn and enjoy the practice of law.

\section{Please contact:}

Marie Huxter

Direct dial: (416) 307-4202

Internet: mhuxter@toronto.langmichener.ca 


\section{Join a Team Dedicated to Excellence}

Challenging, exciting legal work in a flexible rotation.

Pursue your specific interests in the practice of law as a part of our dynamic and innovative team.

DAVIES, WARD \& BECK

DEDICATED TO

EXCELLENCE

\section{Minden Gross Grafstein \& Greenstein} Barristers \& Solicitors

For information concerning our articling program call or write Melissa A. Muskat (416) 369-4327

111 Richmond Street West, Suite 600, Toronto, Ontario, M5H $2 \mathrm{H} 5$ Tel. (416) 362-3711, Fax (416) 864-9223 
